\title{
O juízo acerca do nexo de causalidade e da imputação objetiva depende de reexame de prova, nos termos da Súmula nº 7 do STJ? Uma análise a partir do REsp 1.840.263/SP
}

\section{Does the judgment about causality and objective imputation depend on a re- examination of the evidence in the terms of Precedent $n^{0} 7$ of the brazilian STJ? An analysis from the REsp 1.840.263/SP}

\author{
Adriano Teixeira
}

\section{Felipe Longobardi Campana}

Resumo: Partindo de um caso concreto no qual o Superior Tribunal de Justiça (STJ) deixou de analisar as teses sobre nexo de causalidade e imputação objetiva arguidas pela defesa em sede de recurso especial sob 0 argumento da impossibilidade do reexame de prova, com aplicação da Súmula $n^{0} 7,0$ presente artigo procura responder se essa súmula realmente impede que 0 Tribunal (re)analise esses pressupostos do tipo objetivo ou se eles não exigem reexame de prova e é possível, e até mesmo necessário, que o STJ os aprecie. Para tanto, após concretizar o conteúdo da súmula, indicando a qual juízo de aplicação da lei penal em uma decisão judicial ela faz referência, entende-se que tanto 0 estabelecimento dos conceitos destes pressupostos (premissa maior) quanto a subsunção dos fatos a eles devem ser objeto de (re)análise pelo STJ.

Palavras-chave: nexo de causalidade; imputação objetiva; Súmula n ${ }^{0} 7$ do STJ; reexame de prova.

Abstract: Starting from a specific case in which the STJ did not analyze the theses on causality and objective imputation argued by the defense in the context of a special appeal under the argument of the impossibility of re-examination of evidence, with application of Precedent $n^{0} 7$, this article seeks to answer whether this precedent actually prevents the Court from (re)analyzing these objetictive-type assumptions or whether they do not require re-examination of evidence and it is possible, and even necessary, for the STJ to analyze them. Therefore, after concretizing the contents of the summary, indicating which judgment of application of the criminal law in a court decision it refers to, it is

TEIXEIRA, Adriano; CAMPANA, Felipe Longobardi. O juízo acerca do nexo de causalidade e da imputação objetiva depende de reexame de prova, nos termos da Súmula no 7 do STJ? Uma análise a partir do REsp 1.840.263/SP. Revista do Instituto de Ciências Penais, Belo Horizonte, v. 6, n. 2, p. 521-548, 2021. DOI: 10.46274/1809-192XRICP2021v6n2p521-548 
understood that both the establishment of the concepts of the assumptions (major premise) and the subsumption of the facts to this concepts should be object of (re)analysis by the STJ.

Keywords: causality; objective attribution; Precedent $n^{0} 7$ of STJ; re-examination of evidence.

Sumário: 1 Introdução: 0 caso e a pergunta; 20 significado do "reexame de prova" na Súmula n0 7 do STJ; 2.1 OS juízos realizados pelo magistrado em decisões judiciais na aplicação do Direito Penal; 2.20 conteúdo da Súmula n 7 do STJ; 3 Classificação dogmática das matérias arguidas pela defesa; 3.1 Resultado morte; 3.2 Nexo de causalidade; 3.2.1 Premissa maior; 3.2.2 Premissa menor; 3.2.3 Subsunção; 3.3 Imputação objetiva; 3.3.1 Criação de um risco juridicamente desaprovado; 3.3.1.1 Premissa maior; 3.3.1.2 Premissa menor; 3.3.1.3 Subsunção; 3.3.2 Realização do risco criado no resultado; 3.3.2.1 Premissa maior; 3.3.2.2 Premissa menor; 3.3.2.3 Subsunção; 4 As matérias arguidas pela defesa exigem "reexame de provas"?; 4.1 A análise do nexo de causalidade; $4.2 \mathrm{~A}$ análise da imputação objetiva, especialmente realização do risco no resultado; Conclusão; Referências.

\section{Introdução: 0 caso e a pergunta}

"A" conduzia um veículo pela via pública " $\mathrm{x}^{\prime}$ e, em determinado momento, iniciou o cruzamento da via preferencial " $y$ " sem a devida diminuição de velocidade exigida pela placa "PARE". Em razão disso, chocou-se com a lateral traseira do veículo conduzido pela pessoa "B", que seguia na via preferencial " $y$ ". Devido à colisão, o veículo de "B" ficou desgovernado e atingiu a pessoa "C" na


instâncias ${ }^{2}$ pela prática do crime de homicídio culposo na direção de veículo automotor (art. 302, parágrafo único, II, do CTB).

A defesa de "A" interpôs recurso especial alegando, no mérito, que a decisão do Tribunal a quo teria negado vigência ao art. 13 do Código Penal, sob o argumento de que não havia "indícios do nexo de causalidade entre sua conduta e o resultado morte da vítima", e também negado vigência ao art. 302 do CTB, sob o argumento de que a conduta seria atípica, pois "teria relação com a criação de um risco não permitido de causação de acidente de pequenas proporções, mas jamais de causação de acidente causador de morte" ${ }^{\prime 3}$.

2 Em grau de apelação, o Tribunal de Justiça concluiu que "A" concorreu para o fato, pois "o veículo de ["B"] apresentava danos nos traços médio e posterior de seu lado esquerdo, ou seja, em sua traseira... restou comprovado que foi ["A"] quem colidiu contra o veículo de ["B"]"; que foi "A" quem agiu culposamente, pois não parou na sinalização do cruzamento ou, no mínimo, "se equivocou ao calcular a distância a qual ["B"] estava do cruzamento, bem como o tempo que o mesmo levaria para atravessá-lo" e que o resultado morte de "C" estava "no âmbito de proteção da norma" de cuidado desrespeitada por "A", o que fundamentou sua responsabilidade penal pelo homicídio culposo (STJ, REsp 1.840.263/SP, p. 12-15). 
A $6^{\text {a }}$ Turma do Superior Tribunal de Justiça (adiante, STJ) proferiu decisão negando provimento ao recurso, sob o argumento de que as duas teses levantadas exigiriam "reexame de provas, o que é vedado pelo óbice da Súmula no 7 do STJ" ${ }^{\prime \prime}$. Diante dessa narrativa, indaga-se: As matérias arguidas pela defesa nas razões de recurso especial exigem verdadeiro reexame de provas?

A pergunta é relevante, pois, sendo função do STJ a uniformização da interpretação de lei federal, seria de se lamentar se a Corte deixasse de analisar matérias que dizem respeito aos pressupostos básicos de aplicação dos tipos penais presentes na Parte Especial do Código Penal e em leis esparsas. Conferir tratamento uniforme ou, pelo menos, claro aos requisitos jurídicos fundamentais que irão, ao fim e ao cabo, decidir sobre a privação de liberdade de cidadãos brasileiros afigura-se como tarefa imprescindível.

Neste artigo, será percorrido o seguinte caminho: primeiro será definida a abrangência da proibição contida na Súmula no 7 do STJ (a seguir, item 2). Na sequência, será feita a classificação dogmática das matérias arguidas pela defesa dentro da teoria do delito (a seguir, item 3) e, por fim, será respondida a indagação feita antes sobre se as matérias arguidas estão dentro da proibição do enunciado da Súmula no 7 do STJ (a seguir, item 4).

\section{0 significado do "reexame de prova" na Súmula n0 7 do STJ}

Há vozes na doutrina nacional que afirmam que o conteúdo da Súmula no 7 do STJ não seria passível de interpretação e aplicação racionais ${ }^{5}$. Parte dessa crítica baseia-se na suposta superação da distinção entre "matéria de fato" e "matéria de direito" e na impossibilidade de subsunção "lógica" do caso concreto à norma fixada pelo legislador, tendo em vista que existiriam espaços de interpretação entre o momento da criação de uma lei e o momento de sua aplicação ${ }^{6}$. Para tais críticos, a estanque distinção entre "fato" e "direito" e a pura subsunção não seria possíveis, pois, de um lado, a norma jurídica seria produto de uma construção do intérprete a partir dos fatos do caso concreto, e estes, de outro lado, seriam construídos pelo juiz a partir da referida norma . Ocorre que o enunciado da Súmula

5 Nesse sentido, cf. LOPES JR., Direito processual penal, p. 1672-1674; STRECK, Conjur (22 mar. 2018), [n.p.]; ROSSI, Conjur (24 mar. 2018), [n.p.]; MUDROVITSCH/NÓBREGA, Conjur (31 jul. 2021), [n.p.]. Mencionando outros autores, cf. COTA/SOUZA/PARENTE/OLIVEIRA JÚNIOR, REC 66, p. 100.

7 Nesse sentido, cf. HASSEMER, Introdução à filosofia do direito e à teoria do direito contemporâneas, p. 282 283 e 293-294; FERRAZ JUNIOR, Introdução ao estudo do direito, p. 317. Contrário ao ceticismo da moderna 
no 7 do STJ não depende da aceitação desses pressupostos metodológicos, eis que somente proíbe a revisão de um juízo específico que fazem os magistrados no momento da aplicação do Direito: o juízo sobre o "exame de provas".

Assim, busca-se, aqui, delimitar esse juízo de "exame de provas" e distinguí-lo de outros realizados pelos magistrados na aplicação do Direito, de modo a limitar o efeito devolutivo do recurso especial e, por consequência, conferir maior racionalidade às decisões do STJ na admissibilidade dos recursos especiais em Direito Penal.

\subsection{Os juízos realizados pelo magistrado em decisões judiciais na aplicação do Direito Penal}

Não se pode negar que toda aplicação do Direito por uma decisão envolve a confrontação de uma norma geral a um ou mais fatos $\operatorname{concretos}^{8}$, que, para se distinguir de um simples ato de poder, deve ser fundamentada ${ }^{9}$. Essa fundamentação pressupõe a exposição de todos os passos percorridos pelo magistrado, que podem ser explicitados por um raciocínio silogístico ${ }^{10}$ : construção de uma norma jurídica geral (premissa maior), estabelecimento do fato concreto (premissa menor), aplicação da primeira ao segundo (processo de subsunção) e a apresentação das consequências jurídicas advindas desta subsunção (conclusão) ${ }^{11}$.

Ao aplicador do Direito cabe a tarefa de construção da premissa maior, que, todavia, deve ocorrer dentro dos limites da lei'12, mormente quando se trata da aplicação do Direito Penal, que é guiado pelo princípio da legalidade estrita

hermenêutica jurídica em relação à distinção entre questão de fato e de direito e ao processo de subsunção, cf. SCHÜNEMANN, Gesammelte Werke III, p. 54 s.

8 Nesse sentido, afirma Reale: "A aplicação do Direito envolve a adequação de uma norma jurídica a um ou mais fatos particulares, o que põe o delicado problema de saber como se opera o confronto entre uma regra 'abstrata' e um fato 'concreto', para concluir pela adequação deste àquela (donde a sua licitude) ou pela inadequação (donde a ilicitude)" (REALE, Lições preliminares de direito, p. 300-301).

9 PUPPE, InDret Penal 3/2013, p. 4.

10 FERRAZ JUNIOR, ob. cit. (nota 7), p. 316: "O processo de subsunção, que não se confunde com o automatismo lógico da dedução, exige alguns passos importantes, que já se mostram na própria elaboração da premissa maior". Também considerando que a aplicação do direito não se afastou totalmente do raciocínio de subsunção, COTA/ SOUZA/PARENTE/OLIVEIRA JÚNIOR, ob. cit. (nota 5), p. 99.

11 Este juízo é assim descrito por SCHÜNEMANN, ob. cit. (nota 7), p. 62. Descrevendo este juízo, porém em somente três etapas (premissa maior-premissa menor-conclusão), cf. ENGISCH, Einführung in das juristische Denken, p. 91; FERRAZ JUNIOR, ob. cit. (nota 7), p. 316.

12 Em sentido contrário, Hassemer argumenta que a lei prévia não é capaz de impor tal vinculação à atividade do magistrado. Para o autor, ao entrar em vigor, a lei passa a ficar à disposição do magistrado, que definirá seus contornos, com a atividade de interpretação (HASSEMER, ob. cit. (nota 7), p. 293-294). 


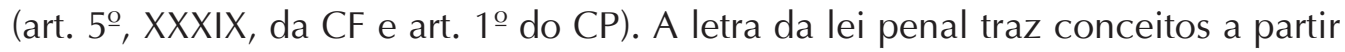
dos quais se pode estabelecer uma zona de consenso, que define claramente o que está incluído e excluído da norma, e também uma zona de dúvida ${ }^{13}$, que exigirá tarefa de interpretação do magistrados nos casos concretos, dentro dos limites do chamado "sentido literal possível"14-15. Além do texto legal, a construção da premissa maior está vinculada a outros elementos, como decisões anteriores (precedentes) e a dogmática jurídica (regras dogmáticas para aplicação do Direito) ${ }^{16}$. Trata-se, portanto, de um juízo de natureza interpretativo-argumentativa. De outro lado, com relação à comprovação da premissa menor, o aplicador do Direito deve verificar a existência ou inexistência do fato concreto, isto é, verificar se o fato histórico descrito na denúncia ocorreu com probabilidade próxima da certeza, tratando-se de uma afirmação fática, que somente pode ser provada ${ }^{17}$.

O processo penal nada mais é do que a reconstrução aproximada do fato histórico narrado e delimitado na denúncia ${ }^{18}$, o que se faz por meio do instrumento denominado "prova"19. O objeto da prova é este fato histórico, e não o crime,

13 Hassemer menciona a possibilidade de se distinguir entre um "núcleo do conceito", que seria inequívoco, e uma "auréola do conceito", que seria vaga e requeriria uma interpretação (HASSEMER, ob. cit., p. 284). Schünemman, valendo-se da metáfora do ovo estrelado, distingue entre "núcleo do significado", gema do ovo, no qual encontram-se os acontecimentos que qualquer uso cotidiano da linguagem designaria com este termo; "periferia do significado", clara do ovo, no qual encontram-se os acontecimentos que o uso cotidiano da linguagem não diria nem que está certo nem que está incorreto o uso do termo para designá-los, o que exige um segundo nível de interpretação, e "resto do mundo", espaço não compreendido pelo ovo, no qual encontram-se os acontecimentos que qualquer uso cotidiano da linguagem com certeza não designiria com este termo (SCHÜNEMANN, Estudos de direito penal, direito processual penal e filosofia do direito, p. 290-291).

14 Ferraz Júnior afirma: "O processo de subsunção tem a ver com o problema da aplicação do direito. A aplicação não se confunde com a interpretação, embora a exija" (FERRAZ JÚNIOR, ob. cit. (nota 7), p. 316). A respeito deste processo de interpretação pelo magistrado, cf. SCHÜNEMANN, ob. cit. (nota 13), p. 291-292; e, também, PUPPE, Enfoques Penales 1, p. 4-5.

15 Nesse sentido, após tratar da superação da distinção estanque entre "norma" e "fato", Reale conclui: "O ato de subordinação ou subsunção do fato à norma não é um ato reflexo e passivo, mas antes um ato de participação criadora do juiz, com a sua sensibilidade e tato, sua intuição e prudência, operando a norma como substrato condicionador de suas indagações teóricas e técnicas" (REALE, ob. cit. (nota 8), p. 302).

16 Destacando estes dois elementos como mais eficazes para a vinculação do magistrado, cf. HASSEMER, ob. cit. (nota 7), p. 296-297. Sobre a força vinculante das regras dogmáticas, cf. Pantaleón Díaz, que afirma a respeito dos critérios ("teorias" ou "posições") dogmáticos alternativos: "Contribuem, por sua vez, a que quem se pronunciou a favor do emprego de um dos critério alternativos de decisão na resolução de um caso concreto se veja obrigado, ou a aplicar o mesmo critério em todos os casos similares que se apresentarem no futuro, ou a distinguir tais casos do já resolvido com base em considerações valorativamente relevantes ou bem motivar suficientemente uma mudança de critério. Tais são, a meu juízo, os serviços mais importantes que uma dogmática jurídico-penal desenvolvida pode prestar à jurisprudência" (PANTALEÓN DÍAZ, Libertas 7, p. 112, tradução livre).

PUPPE, ob. cit. (nota 9), p. 6.

18 LOPES JR., ob. cit. (nota 5), p. 556. 
o tipo penal ou a norma ${ }^{20-21}$. O fato histórico narrado na denúncia já apresenta um recorte relacionado a uma norma penal, o que demonstra a comunicabilidade entre "matéria de fato" e "matéria de direito". Porém, a verificação da premissa menor não é um juízo argumentativo, mas sim cognitivo do magistrado ${ }^{22}$. Como aponta Schünemann ${ }^{23}$, o caso concreto possui uma importância heurística, que delimita a questão jurídica a ser enfrentada, mas que somente pode ser decidida com o estabelecimento da premissa maior.

Portanto, por mais que exista uma comunicabilidade entre a análise de questões de direito e de questões de fato, é possível e necessário distinguir dois juízos para a aplicação do Direito Penal em uma decisão judicial: o magistrado deve interpretar, construir uma norma penal (e/ou suas partes), a partir da lei, de precedentes e das regras dogmáticas (juízo interpretativo-criativo), e, diante da prova produzida ao longo da instrução processual, deve verificar se o fato narrado na denúncia ocorreu com probabilidade próxima da certeza (juízo cognitivo-epistemológico ${ }^{24}$.

Feitos esses dois juízos, o magistrado realizará um confronto entre o fato histórico provado e a norma estabelecida, denominado processo de subsunção ${ }^{25}$,

20 LOPES JR., ob. cit. (nota 5), p. 556.

21 Diante de um fato em que " $A$ " atirou em "B" comumente se afirma: "Está provado que 'A' matou 'B'". Ocorre que essa frase está equivocada, pois matar alguém não é um objeto de prova, mas sim um enunciado de um tipo penal que precisa ser corretamente aplicado. O objeto da prova é o fato histórico. Portanto, o correto seria afirmar: "Está provado que 'A' desferiu um tiro com uma arma de fogo no coração de 'B' e que este, em razão dos efeitos do tiro em seu corpo, sofreu uma parada dos sistemas respiratório e cardiovascular". A partir deste fato histórico provado, deve-se afirmar ou não se "A" matou "B", ou seja, passa-se à subsnção e à conclusão, nas quais se realizará a aplicação da premissa maior à menor e se responderá à pergunta sobre se "A" será responsável por homicídio.

22 Segundo Lopes Jr., "é a prova que permite a atividade recogniscitiva do juiz em relação ao fato histórico (story of the case) narrado na peça acusatória" (LOPES JR., ob. cit. (nota 5), p. 557).

23 SCHÜNEMANN, ob. cit. (nota 7), p. 60.

24 Deixando clara a diferença entre estes dois juízos, afirma Lopes: "E quando não existe clareza na premissa maior e nem certeza quanto à verdade do enunciado da menor, como inferir daí a conclusão a um tempo válida e verdadeira? A resposta pode tomar dois caminhos ou justificativas: ou a decisão é livre e o julgador decide como quiser, ou tornar-se necessário afirmar a existência de critérios seguros para obter-se a clareza da premissa maior (o problema dos métodos de interpretação do direito) e verificabilidade da menor (o problema das provas dos fatos)" (LOPES, ob. cit. (nota 6), p. 238). Puppe esclarece: "Os enunciados jurídicos podem ser fundamentados, as afirmações fáticas somente podem ser provadas. Por fim, somente deveríam ser reconhecidas perante o Tribunal como afirmações fáticas aquelas proposições que sejam inerentemente demonstráveis. Este é o critério do sentido empírico" (PUPPE, ob. cit. (nota 9), 6, tradução livre).

25 Schünemann esclarece: "A subsunção sucede assim que a descrição coloquial dos fatos $f$ de acordo com a linguagem cotidiana na premissa menor corresponda ao âmbito nuclear, traduzido em linguagem cotidiana, do conceito jurídico e na premissa maior" ("Die Subsumtion ist gelungen, sobald die umgangssprachliche Sachverhaltsbeschreibung $f$ im Untersatz zum umganssprachlichen Kernbereich des Rechtsbegriffes e im Obersatz gehört") (SCHÜNEMANN, ob. cit. (nota 7), p. 64). 
do qual seguirão as consequências jurídicas (conclusão). Cada uma das etapas desse raciocínio exposto na decisão judicial pode ser objeto de impugnação pelas partes por meio de recursos. Tome-se como exemplo uma decisão que condenou o réu pelo crime de furto (art. 155 do $\mathrm{CP}$ ). O réu pode recorrer, afirmando, por exemplo, que o termo "coisa", disposto no art. 155 do CP, tem conceito diverso daquele atribuído pelo magistrado na sentença ou que houve equívoco quanto à escolha da regra dogmática que define o dolo (exemplos de impugnação da etapa da premissa maior). Por outro lado, há a opção de recorrer afirmando que, diversamente do que verificou o magistrado, as provas indicam que não foi o réu o autor da subtração (exemplo de impugnação da etapa da premissa menor). Há ainda a possibilidade de recorrer alegando que o correto conceito de "coisa" ou a correta regra do dolo estabelecidos pelo magistrado na sentença foram mal aplicadas ao caso em questão (exemplos de impugnação do processo de subsunção). Quais instâncias revisoras deverão enfrentar todas as etapas da aplicação do Direito na decisão judicial e quais deverão enfrentar somente algumas, é questão a ser decidida pelo legislador. Pode-se dizer, usando a linguagem da teoria do direito, que o legislador brasileiro estabeleceu, no art. 105, III, da CF, que ao STJ não cabe rever a construção da premissa menor, mas tão somente da premissa maior e o posterior processo de subsunção. O conteúdo da Súmula no 7 decorre dessa decisão. Vejamos.

\subsection{0 conteúdo da Súmula $\mathrm{n}^{0} 7$ do STJ}

Feita a exposição, necessário delimitar quais dessas etapas da decisão judicial penal podem e quais não podem ser impugnadas por um recurso especial, nos termos da Súmula no 7 do STJ. A Súmula dispõe que "a pretensão de simples reexame de prova não enseja recurso especial", o que obriga a delimitar e preencher de conteúdo o termo "reexame de prova". Para tanto, é necessário guiar-se pela função do recurso especial no sistema recursal. O recurso especial é aquele por meio do qual se procura preservar a autoridade e integridade da legislação federal, uniformizando sua interpretação e aplicação no País ${ }^{26}$, razão pela qual somente pode impugnar a parte da decisão judicial penal que apresente defeitos relacionados a esses aspectos de análise da lei federal.

A comprovação da premissa menor por meio do juízo cognitivo, em que o magistrado analisa as provas produzidas e constata se o fato histórico da denúncia 
ocorreu com certa probabilidade ${ }^{27}$, não diz respeito à autoridade e à integridade da lei federal, razão pela qual não é cabível sua impugnação por meio do recurso especial ${ }^{28}$. Por outro lado, a construção da premissa maior, na qual o magistrado realizará a interpretação do conteúdo dos conceitos da norma penal e das regras dogmáticas para construir/aplicar a norma, diz respeito à interpretação de lei federal, não existindo dúvida de que pode ser objeto de impugnação por meio de recurso especial.

O processo de subsunção é o que pode trazer maior dúvida, na medida em que trata do momento em que se realiza um cotejo da afirmação fática estabelecida na premissa menor com o conteúdo da premissa maior. Em um primeiro olhar, pode-se entender que esse processo não poderia ser impugnado por meio de recurso especial, pois não estaria relacionado com o conteúdo abstrato da lei federal, mas sim com a simples resolução de um caso concreto, afastando-se da função revisora do STJ ${ }^{29}$.

Porém, este é um entendimento equivocado, pois, diferentemente das afirmações fáticas estabelecidas nas premissas menores, que são circunstancialmente demonstradas por provas, o processo de subsunção, tal qual o estabelecimento das premissas maiores, pode se transformar em enunciado geral, que deverá ser aplicado a fatos posteriores semelhantes, como verdadeiros enunciados jurídi$\cos ^{30}$. O fato de o processo de subsunção se basear em circunstâncias da afirmação fática da premissa menor não significa que ele se torna um enunciado objeto da prova processual. Ao contrário, essas circunstâncias da afirmação fática feita na premissa menor são integrantes do processo de subsunção, diferentemente das provas, que não compõem a afirmação fática, mas somente a demonstram³1.

27 As questões sobre os conhecimentos científicos, fatos notórios, princípios gerais de experiência para valoração da prova também poderão ser objeto de impugnção por recurso especial. Sobre essa questão, cf. infra, item 3.2. No mesmo sentido, BADARÓ, ob. cit. (nota 26), p. 285; e COTA/SOUZA/PARENTE/OLIVEIRA JÚNIOR, ob. cit. (nota 5), p. 103. A impugnação sobre a forma como foi feita a valoração da prova pode ser objeto de recurso especial e extraordinário, porém será uma situação de falta ou defeito de fundamentação da decisão, ou seja, um error in procedendo - e não um error in judicando -, que poderá gerar nulidade da decisão. Em sentido contrário, Cota e colaboradores, para quem trata-se de hipótese de "qualificação jurídica dos fatos", que pode ser objeto de recurso especial (COTA/SOUZA/PARENTE/OLIVEIRA JÚNIOR, ob. cit. (nota 5), p. 104).

28 Afirma Badaró: "Como seu objetivo precípuo não é fazer justiça no caso concreto, não há preocupação com as questões de fatos terem sido bem ou mal resolvidas à luz das provas produzidas" (BADARÓ, ob. cit. (nota 26), p. 280).

29 Denuncia-se, atualmente, uma verdadeira jurisprudência defensiva das Cortes Superiores sempre argumentando pela existência de "questões de fato" e rejeitando os recursos. Nesse sentido, cf. BADARÓ, ob. cit. (nota 26), p. 281; e COTA/SOUZA/PARENTE/OLIVEIRA JÚNIOR, ob. cit. (nota 5), p. 107-108. 
Assim, pode-se afirmar que também o processo de subsunção realizado em uma sentença, por se tratar da verificação do encaixe da premissa menor à maior com pretensão de generalização, diz respeito à integridade e vigência da lei federal, que deve ser objeto de impugnação por recurso especial ${ }^{32-33}$. Essa posição é reforçada pelo argumento de que, ao ser chamado a se pronunciar com a interposição de um recurso especial, o STJ é dotado de poder de modificação da decisão a quo, ou seja, tem poder de verdadeira aplicação da norma ao caso $^{34}$, e não de simples cassação da decisão, situação em que somente enunciaria a norma correta e anularia a decisão a quo para que outra fosse proferida ${ }^{35}$.

Portanto, é cabível e necessária a devolução ao STJ, por meio do recurso especial, da construção da premissa maior e realização do processo de subsunção na aplicação do Direito Penal pela decisão judicial: caso o error in judicando da decisão a quo esteja no estabelecimento da premissa maior (interpretação de al-

32 Nesse sentido, afirma Lopes Jr.: "O que ambas as súmulas vedam é o 'simples' reexame da prova, o que não impede, portanto, a discussão sobre a qualificação jurídica dos fatos, ou seja, o juízo de tipicidade realizado pelo Tribunal a quo no caso concreto. A discussão situa-se na incidência ou não da norma penal no caso em julgamento, a interpretação dada e os limites semânticos do tipo..." (LOPES JR., ob. cit. (nota 5), p. 1672). No mesmo sentido, BADARÓ, ob. cit. (nota 26), p. 285. Próximo, porém com as diferenças do sistema recursal alemão, PUPPE, ob. cit. (nota 9), p. 11.

33 Entendimento próximo, mas que não é frutífero pela falta de clareza, é o que pretende distinguir a situação de "reexame de prova" da situação de "revaloração da prova" para afirmar que, na segunda, é permitida a interposição de recurso especial. Nesse sentido, cf. o AgRg-AREsp 1786455, julgado pelo STJ, no qual debatia-se se estava presente ou não a necessária "permanência" para que a conduta fosse típica do crime de associação criminosa. O Tribunal entendeu que seria possível avaliar a questão em sede de REsp, pois não se trataria de "reexame de prova", mas sim de "revaloração da prova" (STJ, AgRg-AREsp 1786455, 6ª T., Min. Rel. Olindo Menezes, J. 08.06.2021), e cf. também Cota e colaboradores, que mencionam um caso no qual a Defensoria Pública interpôs recurso especial argumentando que a conduta de furto praticada enquadrava-se no princípio da insignificância, mas o Tribunal de Justiça do Tocantins não admitiu por entender que havia violação da Súmula $n^{\circ} 7$ e a Defensoria interpôs agravo em recurso especial alegando se tratar de "revaloração da prova" e não "reexame de prova" (COTA COTA/SOUZA/PARENTE/OLIVEIRA JÚNIOR, ob. cit. (nota 5), p. 108). 0 que se denomina "revaloração da prova" é, na verdade, a confrontação do fato concreto provado à norma abstrata, ou seja, o que aqui denominamos de processo de subsunção, que também pode ser objeto de impugnação por recurso especial. No caso da discussão sobre o elemento "permanência" da associação criminosa, este não será objeto de prova, o que se prova é a forma como está organizada uma determinada associação de pessoas. Na sequência, demonstrado que esta forma de organização narrada na denúncia acontecia com probabilidade próxima da certeza, cabe ao magistrado verificar se esta forma de organização da associação enquadra-se ou não no conceito "permanente". No caso da discussão sobre a aplicação do princípio da insignificância, estava demonstrado com probabilidade próxima da certeza que o indivíduo havia substraído determinada quantia, sendo necessário verificar somente se tal quantia se enquadrava no conceito abstrato de "insignificância". Pode-se concluir, assim, que já se admite a impugnação da etapa do processo de subsunção por recurso especial, mas por meio de um conceito pouco claro e sem delimitação ("revaloração da prova") e que, por conta disto, não confere a necessária segurança jurídica.

34 Esse é o texto do art. 1.034 do Código de Processo Civil: "Admitido o recurso extraordinário ou o recurso especial, o Supremo Tribunal Federal e o Superior Tribunal de Justiça julgará o processo, aplicando o direito". Próximo, cf. PUPPE, ob. cit. (nota 9), p. 11. 
gum elemento típico ou estabelecimento de regra dogmática), o recurso especial deve ser fundamentado na hipótese de contrariedade à lei federal (art. 105, III, alínea a, segunda parte, da CF); e, caso o error in judicando da decisão esteja no processo de subsunção da afirmação fática provada à norma penal e às regras dogmáticas, o recurso especial deve ser fundamentado na hipótese da negativa de vigência da lei federal (art. 105, III, alínea a, terceira parte, da CF). Conclui-se, assim, que o conteúdo da Súmula no 7 do STJ consiste somente na revisão da parte da sentença ou do acórdão a quo ("reexame"), que verifica se o fato histórico narrado na denúncia ocorreu ou não com probabilidade próxima da certeza ("de provas" $\left.^{\prime \prime}\right)^{36-37}$.

\section{Classificação dogmática das matérias arguidas pela defesa}

A narrativa do caso em questão impõe ao intérprete do Direito a pergunta sobre se a condutora " $\mathrm{A}$ " pode ser penalmente responsabilizada pela morte do pedestre "C" $\mathrm{C}^{\prime 38}$. A tipicidade de uma conduta de homicídio culposo na direção de

36 Nesse sentido, apesar de destacar a dificuldade da distinção, afirma Badaró: "Não cabe recurso especial ou extraordinário para a impugnação quanto à matéria fática. Em outras palavras, trata-se de recurso que se presta a atacar 'questão de fato' e não 'questão de direito'. Há erro de fato quando o acórdão se funda em uma falsa premissa de fato, decorrente da errônea valoração das provas. Há um vício na atividade heurística..." (BADARÓ, ob. cit. (nota 26), p. 284). Em sentido próximo, Cota e colaboradores afirmam: "Reexaminar seria a análise contundente do meio probatório, considerando os termos 'quem, o que, onde' ..., atributos de competência dos Tribunais a quo - por meio do princípio do livre convencimento motivado -, responsáveis pelo julgamento dos recursos ordinários..." (COTA/SOUZA/PARENTE/OLIVEIRA JÚNIOR, ob. cit. (nota 5), p. 102). No entanto, os autores adotam a distinção entre "reexame de prova", que não pode ser objeto de recurso especial, e "revaloração de prova" e "questões de qualificação jurídica dos fatos", que podem ser objeto de recurso especial. A distinção não é clara, conforme demonstrado na nota de rodapé 33, e os casos mencionados para exemplificar essas duas classificações são amplamente resolvidos pela posição que ora se defende (os de "revaloração" são hipóteses de exercício da etapa do process de subsução, e os de "questões de qualificação" são hipóteses de error in procedendo na fundamentação da decisão), razões pelas quais não foi aqui adotada.

37 Essa limitação do conteúdo da súmula pode ser observada nos precedentes que ensejaram sua edição. Por exemplo: No AgRg-Ag 148, a discussão era sobre a inexistência de "indícios bastantes para acarretar a pronúncia do recorrido e ora agravado" (STJ, AgRg-Ag 148, 6ª. T., Min. Rel. Carlos Thibau, J. 05.12.1989); no REsp 290, a discussão era sobre se havia prova ou não de que o réu era portador de uma doença venérea para fins do crime de perigo de contágio venéreo, art. 130 do CP (STJ, REsp 290, 5a T., Min. Rel. José Dantas, J. 02.10.1989), e no REsp 305, a discussão era sobre se as provas dos autos demonstravam manifestamente que o réu era instigador do crime de homicídio, contrariamente do que o júri havia decidido (STJ, REsp 305, 5a T., Min. Rel. Flaquer Scartezzini, J. 19.02.1990).

38 Para analisar a responsabilidade penal de "A", seguiremos aqui o esquema de análise do denominado Gutachtenstil, método de análise de caso aplicado nas universidades alemãs. Para mais informações sobre o método, cf. HILGENDORF/VALERIUS, Direito penal PG; e QUARCH, Revista de Direito Civil Contemporâneo 1, p. 251-285. A escolha pela utilização deste método no presente artigo fundamenta-se, além das vantagens políticas e de clareza argumentativa a ele inerentes, no fato de que se baseia na aplicação do raciocínio de subsunção antes exposto, subdividido em cada um dos pressupostos de responsabilidade penal, permitindo que se evidencie o que 
veículo automotor (art. 302 do Código de Trânsito Brasileiro) ${ }^{39}$ depende dos seguintes pressupostos: (3.1) resultado morte; (3.2) nexo de causalidade; (3.3) imputação objetiva ${ }^{40}$; (3.3.1) conduta criadora de um risco juridicamente desaprovado; e (3.3.2) realização desse risco no resultado ${ }^{41}$.

\subsection{Resultado morte}

O tipo penal de homicídio na condução de veículo automotor exige a presença de um resultado morte da vítima, que pode ser entendido como a parada de suas atividades cardiorrespiratórias (premissa maior). No caso, segundo consta do acórdão, "C" teve uma parada cardiorrespiratória (premissa menor), o que permite concluir que o resultado morte exigido pelo tipo está presente (subsunção).

é matéria de direito (estabelecimento da premissa maior e a subsunção) e o que é matéria de fato e, portanto, que exige exame de provas (estabelecimento da premissa menor).

39 Partimos já da análise deste tipo penal por duas razões: (i) essa era a acusação que constava do caso, não cabendo, para o escopo do presente artigo, postular outros possíveis tipos penais pelos quais a condutora "A" poderia ser responsabilizada, como, por exemplo, homicídio doloso; e (ii) seguindo, no Gutachtenstil, as máximas da alternatividade, que exige que se inicie primeiro pelo que se vai afastar, e da fecundidade, que exige que se faça o esquema que vai gerar o maior número de problemas possível, quando o caso evidencia que não há controvérsias sobre se há ou não responsabilidade a título de dolo, não é necessário fazer considerações sobre a inexistência de responsabilidade penal dolosa para só depois analisar a responsabilidade a título culposo, sendo possível, já de início, a análise do tipo culposo. No caso, o fato de que "A" sequer viu a passagem do veículo de "B" e, principalmente, a presença de "C" na faixa de pedestres demonstram que não há o necessário conhecimento para afirmar a presença do dolo (art. 20 do CP). Portanto, a própria dinâmica dos fatos autoriza a iniciar a análise da responsabilidade penal de "A" já pelo título culposo, que é a mais frutífera. Por se tratar de tipo penal especial em relação ao art. $121, \S 3^{\circ}$, do Código Penal, seguiremos a análise com base no tipo penal do art. 302 do CTB. Poder-se-ia argumentar que a tipicidade objetiva do tipo doloso já contempla a do tipo culposo, de modo que não faria diferença iniciar por um ou por outro. Ocorre que, no caso em questão, por se tratar de um tipo especial, que é o homicídio culposo na direção de veículo automotor, iniciar a análise pelo homicídio doloso exigiria a verificação da tipicidade objetiva do art. 121 do CP, a negativa da tipicidade subjetiva e, então, novamente a análise da tipicidade objetiva do art. 302 do CTB.

40 Essa disposição dos critérios relacionados à teoria da imputação objetiva segue a organização tradicional a partir da concepção apresentada originalmente por ROXIN, Estudos de direito penal, p. 101-131. Entre nós, GRECO, Funcionalismo e imputação objetiva no direito penal, p. 57-61. Frisch apresenta organização diversa para os critérios que integram a imputação objetiva, dividindo entre "comportamento típico", que cuidaria do desvalor da conduta como uma conduta criadora de um risco juridicamente desaprovado, e "imputação do resultado", que cuidaria do desvalor do resultado como a atribuição do resultado lesivo à referida conduta. Cf. FRISCH, Causalidad, riesgo e imputación, p. 373-381. Próxima a esta posição, PUPPE, InDret Penal 1/2021, p. 595. Entedendo que a distinção proposta por Frisch é meramente terminológica e supérflua quando se adota uma postura de distinção entre o momento de análise ex ante, que define a norma de comportamento e se vale dos conhecimentos do autor, e o momento de análise ex post, que será o da realização da imputação objetiva strictu sensu, que se vale também de fatos conhecidos posteriormente, cf. SCHÜNEMANN, Temas actuales y permanentes del derecho penal después del milenio, p. 392-396. Próximo, GRECO, Um panorama da imputação objetiva, p. 34.

41 A análise aqui se limitará ao pressuposto da tipicidade objetiva. Não serão objeto da análise questões relacionadas à antijuridicidade ou à culpabilidade, pois não foram objeto de impugnação pelo recurso da defesa. 


\subsection{Nexo de causalidade}

Neste ponto encontra-se a primeira matéria arguida pela defesa nas razões de recurso especial, ao afirmar que houve negativa de vigência ao art. 13, caput, do CP.

\subsubsection{Premissa maior}

O nexo de causalidade é uma relação empiricamente demonstrada entre dois eventos, de modo a afirmar que o primeiro é a causa do segundo, que será sua consequência. No Direito Penal, duas questões precisam ser definidas para se afirmar este nexo: (i) uma lei natural causa ${ }^{42}$, isto é, a demonstração científico-empírica da relação entre os dois eventos; e (ii) o tipo de relação que se exige no Direito Penal para afirmar que um desses eventos é causa do outro, isto é, uma relação necessária ou uma relação suficiente. De acordo com o Código Penal brasileiro, que em seu art. 13, caput, adotou a teoria da conditio sine qua non ${ }^{43}$, causa é toda condição necessária para o resultado ${ }^{44}$, ou seja, um evento será causa de um resultado quando sem o primeiro o segundo não ocorreria, o que se verifica com a supressão hipotética da possível causa e a subsequente constatação de que, com tal supressão, o resultado desapareceria segundo uma lei causal natural. Há discussão doutrinária sobre qual o conceito de "causa" que se deve adotar no Direito Penal45,

42 Conforme afirma Greco, há uma "necessidade lógica de que toda aplicação da conditio-sine-qua-non transcenda ao caso concreto e postule generalizações ('leis naturais'). Não há como saber se, subtraindo mentalmente A, B desapareceria, a não ser que já se disponha de uma lei geral conectando eventos da classe de A com eventos da classe de B" (GRECO, Problemas de causalidade e imputação objetiva nos crimes omissivos impróprios, p. 62-63).

43 Sobre a teoria da equivalência das condiôes, conhecida pela fórmula conditio sine qua non, cf. ROCHA, A relação de causalidade no direito penal, p. 80-98.

44 A reforma da Parte Geral do Código Penal brasileiro de 1984 manteve a redação original do art. 11, somente transferindo-a para o atual art. 13, caput. Portanto, sobre o conceito de causa para o Código Penal brasileiro, cf. HUNGRIA, Comentários ao Código Penal, v. I, t. II, p. 63-66; e, também, ROCHA, ob. cit. (nota 43), p. 162-169.

45 Sobre essa discussão, Puppe defende um conceito de causa, não como uma condição necessária para o resultado (teoria da conditio), mas sim como uma componente necessária de uma condição suficiente para o resultado segundo leis da natureza (PUPPE, El derecho penal como ciencia, p. 221). Esse conceito se mostra vantajoso em relação ao conceito da conditio por duas razões: (i) melhor tratamento do problema das causas substitutivas (ex.: "A" sofreu uma parada cardiorrespiratória em razão de um veneno que Ihe foi aplicado por "B". Porém, ao se realizar a autópsia, descobre-se que uma ponte de safena romperia e que "A" morreria da mesma forma), pois enquanto para o conceito da conditio qualquer causa substitutiva conduz a negar a relação de causalidade (a conduta de ministrar veneno praticada por "B" não é causal, pois, sem ela, "A" teria morrido pelo rompimento da ponte de safena), para o conceito da condição mínima suficiente a causa substitutiva, por não ter ocorrido, não é parte da explicação suficiente e não deve ter relevância (A conduta de ministrar veneno praticada por "B" é causal, pois foi uma componente da condição suficiente para a ocorrência do resultado morte). Repare ainda que não é qualquer componente da condição suficiente que importa, pois, do contrário, se correria o risco de qualquer acontecimento concreto ser considerado como causa, mas sim somente as componentes necessárias. 
porém seguiremos com a teoria da conditio devido à sua adoção expres$\mathrm{sa}^{46-47}$.

Assim, pode-se afirmar que, para o Direito Penal brasileiro, causa é toda condição necessária para o resultado segundo as necessárias leis naturais para cada evento. Para os eventos em questão, as leis naturais dão conta de que (i) a colisão de um veículo em determinada velocidade com a parte lateral-traseira de outro veículo em outra velocidade ${ }^{48}$ resulta em um desgoverno da direção do segundo; que (ii) a colisão de um veículo em determinada velocidade com o corpo humano resulta em danos graves; e que (iii) esses danos graves resultam na parada cardiorrespiratória.

\subsubsection{Premissa menor}

No presente caso, demonstrou-se com probabilidade próxima da certeza que houve a colisão do veículo de "A" com a lateral-traseira do veículo de "B", que modificou sua direção; que houve uma colisão subsequente deste veículo de " $B$ " com o pedestre "C", que sofreu danos em seu corpo e que esses danos resultaram na parada cardiorrespiratória.

Assim, a elimitação hipotética não é de qualquer acontecimento do mundo, mas sim de uma explicação causal já estabelecida (idem, ibidem, p. 222; e PUPPE, InDret Penal 4/2008, p. 1-14); e (ii) melhor tratamento do problema das causas cumulativas (ex.: "A" aplica $1 \mathrm{ml}$ de veneno em "B" e, posteriormente, "C" aplica mais $1 \mathrm{ml}$ de veneno em "B". Sabe-se se $1 \mathrm{ml}$ é suficiente para a morte), pois enquanto para o conceito da conditio uma causa cumulativa conduz a negar a relação de causalidade da outra (A conduta de "A" não é causal, pois "B" teria morrido com a conduta de "C" e a conduta de "C" não é causal, pois " $\mathrm{B}$ " teria morrido com a conduta de " $\mathrm{A}$ "), para o conceito da condição mínima suficiente, cada uma das causas é, por si só, uma condição mínima e, por consequencia, causal para o resultado (nesse sentido, ibidem, p. 14-16). Sobre o conceito da condição mínima no direito penal, cf., também, ROCHA, ob. cit. (nota 43), p. 143-169.

46 A favor da possibilidade de adotar o conceito de causa da teoria da condição mínima já de lege lata no Direito Penal brasileiro (GRECO, ob. cit. (nota 42), p. 63-64). Entendendo que somente modificações de lege ferenda permitiriam outros conceitos de causa que não o de ser uma condição necessária no Direito Penal brasileiro (ROCHA, ob. cit. (nota 43), p. 167).

47 Repare que, caso se entenda que a letra do art. 13, caput, do CP admite um conceito de causa que não seja o da teoria da conditio, é possível arguir em sede de recurso especial que o conceito de causa adotado na sentença ou no acórdão a quo foi equivocado.

48 Importante aqui fazer alguns esclarecimentos a respeito de um possível problema de concausas. Do que é possível extrair do acórdão, durante o julgamento do caso em primeira e segunda instâncias, surgiu a discussão sobre se 0 motorista "B" estaria dirigindo em velocidade acima da permitida e, por conta disso, também teria não só realizado uma causa para o resultado, mas infringido uma norma de segurança (dever de cuidado). A partir desta informação, poder-se-ia questionar, com base no art. $13, \S 1^{\circ}$, do CP, se estaríamos diante de um problema de concausas que afetaria a responsabilidade penal de "A". No entanto, além de essa informação não ter sido provada (p. 12 do acórdão), entendemos que sua correta análise não deve ser feita no momento causalidade, mas sim no momento da imputação objetiva, mais especificamente sobre se o risco criado por "A" se realizou no resultado ou se a conduta violadora do dever de cuidado de "B" impede a imputação do resultado à conduta de "A". Assim, trataremos dessa questão no seu local dogmaticamente correto, o item infra, 3.3.2, nota de rodapé 82. 


\subsubsection{Subsunção}

Assim, a partir da lei natural estabelecida, suprimindo mentalmente a conduta de cruzar a via preferencial de " $A$ ", seu veículo não teria colidido com o veículo de "B" e, por consequência, o resultado morte de " $C$ " deixaria de existir. Logo, pode-se afirmar que a conduta de " $\mathrm{A}$ " de cruzar a via preferencial é causa do resultado morte, pois condição sem a qual a morte de "C" não teria ocorrido. Seria possível, em tese, impugnar por meio de recurso especial tanto o estabelecimento da premissa maior, discordando do conceito de causa como condição necessária adotado pela decisão a quo, quanto da subsunção, discordando da aplicação da premissa maior aos fatos.

\subsection{Imputação objetiva49-50}

Seguindo a análise do tipo objetivo, o conteúdo mínimo comum das diferentes posições ${ }^{51}$ que adotam a teoria da imputação objetiva é o estabelecimento de requisitos normativos necessários para que se possa afirmar que a conduta, que foi causa do resultado lesivo, realizou o tipo objetivo e é proibida pelo Direi-

49 Adotamos aqui a teoria da imputação objetiva por entender que, desde o seu surgimento com os trabalhos de Roxin, os critérios por ela postulados vêm se consolidando como necessários para a verificação da responsabilidade penal em crimes de resultado e lesão. Na Alemanha, já é vista como doutrina dominante há bastante tempo (cf., por todos, RENGIER, Strafrecht AT, p. 84). No Brasil, igualmente é amplamente reconhecida pelos manuais atuais (cf., por todos, MARTINELLI/SCHMITT DE BEM, Lições fundamentais de direito penal PG, p. 528-545) e já adotada pela jurisprudência (cf. STJ, HC 68871). Não ignoramos o fato de que não há previsão legal expressa desta teoria, porém acreditamos que esse não é um óbice à sua aplicação no Brasil por três motivos: (i) a "teoria" nada mais é do que a postulação de critérios para responsabilizar indivíduos por resultados lesivos e, por tal razão, sua construção está implícita nos tipos penais de resultado (na Alemanha, onde surgiu, não há qualquer previsão legal a esse respeito, por exemplo); (ii) acreditamos que o legislador faz bem enquanto mantém sem uma previsão legal, pois se trata de matéria a ser analisada e desenvolvida pelo trabalho dogmático e não por uma definição legal; (iii) o art. 13, caput, do CP não impede sua aplicação, que pode ainda se apoiar no art. $13, \S 1^{\circ}$, do $\mathrm{CP}$, conforme argumentado por GRECO, ob. cit. (nota 40), p. 170-174.

50 Importante ressalvar que, para os fins da temática deste artigo, que é a verificação, entre os pressupostos de tipicidade objetiva, daquilo que pode e daquilo que não pode ser impugnado por recurso especial, os temas que serão tratados neste item poderiam ser tratados tão somente sob a rubrica da causalidade, caso se partisse, por exemplo, do paradigma causalista (o que não fazemos). Assim, teriam de ser manejadas, como era feito por autores mais antigos, as teorias da causalidade adequada e da relevância (sobre elas, cf. GRECO, Luís. A teoria da imputação... ob. cit., p. 23-30; e ROCHA, ob. cit. (nota 43), p. 99-106). Contudo, a questão de fundo do artigo permaneceria a mesma: revisibilidade dos pressupostos jurídicos da tipicidade objetiva.

51 As divergências entre os adeptos da teoria da imputação objetiva encontram-se no conteúdo dos diferentes critérios, conforme será demonstrado ao longo deste tópico, porém todos partem de um quadro teórico mínimo comum. 
to Penal ${ }^{52-53}$, que são a criação de um risco juridicamente desaprovado (infra, item 3.3.1) e a realização do risco no resultado (infra, item 3.3.2).

\subsubsection{Criação de um risco juridicamente desaprovado}

Considerando que cabe ao Direito Penal a tutela subsidiária de bens jurídicos por meio de prevenção geral ${ }^{54}$, suas normas incorporadas nos tipos penais não podem proibir meras causações de resultados lesivos, mas somente condutas humanas perigosas para tais bens jurídicos ${ }^{55}$. Porém, nem toda conduta perigosa a bens jurídicos está proibida, somente a que esteja desaprovada pelo ordenamento jurídico, sob pena de se paralizar a vida social ${ }^{56}$.

\subsubsection{Premissa maior}

A criação do risco deve ser verificada a partir da chamada prognose póstuma objetiva, o que significa dizer que é preciso avaliar, a partir de um observador objetivo e no momento em que a conduta era praticada (ex ante), se esta criaria ou aumentaria a probabilidade de ocorrência do resultado ${ }^{57}$.

A desaprovação jurídica desse risco, por sua vez, deve ser verificada a partir de um juízo de ponderação entre a necessidade de proteção do bem jurídico e a liberdade de agir no caso concreto. O risco será juridicamente desaprovado quando a necessidade de proteção do bem jurídico for superior ${ }^{58}$. Essa ponderação, no entanto, não precisa ser feita a cada novo caso concreto, existindo parâmetros para que seja resolvida, como normas de segurança, jurídicas ou téc-

52 Nesse sentido, cf. FRISCH, La imputación objetiva del resultado, p. 50-52.

53 Por serem critérios dogmáticos inerentes a qualquer tipo penal de resultado, a incorreta aplicação desses critérios pode ser considerada como negativa de vigência ao próprio tipo penal.

54 Por todos, SCHÜNEMANN, Estudos de direito penal, direito processual penal e filosofia do direito, p. 69 ss.; ROXIN/GRECO, Strafrecht AT I, p. 26 ss.

55 GRECO, Funcionalismo e imputação objetiva no direito penal, p. 79-81; e GRECO, Um panorama da imputação objetiva, p. 35-38.

56 GRECO, Funcionalismo e imputação objetiva no direito penal, p. 82-84; e GRECO, Um panorama da imputação objetiva, p. 50-51.

57 GRECO, Um panorama da imputação objetiva, p. 38-39; e FRISCH, ob. cit. (nota 52), p. 60. Entendendo que, neste momento da análise, não se deve utilizar a figura do observador objetivo, mas sim os conhecimentos do próprio autor, afirma Schünemann: "A norma de conduta, cuja infração constitui a conduta típica, deve ser formulada ex ante e deve tomar como ponto de partida a situação como assim também os conhecimentos do autor. Pois ela não deve regular caso hipotético algum, mas sim a conduta do autor individual em uma situação histórica muito concreta. Como nenhuma pessoa pode fazer uso de outra coisa que não seja o seu próprio saber e suas próprias capacidades de conhecer, não teria sentido, em absoluto, construir a norma de conduta partindo da base de conhecimentos de algum observador ótimo imaginário..." (SCHÜNEMANN, ob. cit. (nota 40), p. 393).

GRECO, Um panorama da imputação objetiva, p. 52-58. Mencionando a "utilidade ou necessidade social" da conduta para afastar a desaprovação jurídica da criação do risco, FRISCH, ob. cit. (nota 52), p. 67-70. 
nicas ${ }^{59}$, o princípio da confiança e o parâmetro do homem prudente. Em suma, é preciso que a conduta considerada como causa do resultado lesivo tenha criado um risco àquele bem jurídico e que seja um risco não permitido pelo ordenamento jurídico.

\subsubsection{Premissa menor}

No caso, conforme informações do acórdão, as provas dos autos demonstraram com probabilidade próxima da certeza que a condutora " $\mathrm{A}$ " cruzou a via preferencial sem respeitar o sinal de "PARE" e, na sequência, houve a colisão com o veículo "B".

\subsubsection{Subsunção}

De um ponto de vista do momento da realização da conduta (ex ante) por um observador objetivo, a conduta de "A" aumenta a probabilidade de ocorrência do resultado morte por colisões. Quando alguém atravessa um cruzamento com seu veículo sem olhar, em uma situação de tráfego intenso, cresce a chance de ocorrência de colisões. Além disso, esse risco de morte criado não era autorizado pelo ordenamento, na medida em que existia uma norma de segurança expressa de "PARE" no local em que efetivou o cruzamento e a condutora "A" não a respeitou. Logo, com sua conduta, "A" criou um risco juridicamente desaprovado de morte.

Ao acusado seria possível impugnar por meio de recurso especial tanto o estabelecimento da premissa maior, discordando dos conceitos de risco e de desaprovação jurídica, quanto da subsunção, discordando que cruzar uma via preferencial sem olhar significa a criação de um risco de morte, inclusive para pedestres, e/ou discordar do entendimento de que o desrespeito à placa "PARE" é o descumprimento de uma norma de segurança que torna a criação do risco desaprovada. Porém, não seria possível impugnar a demonstração da afirmação

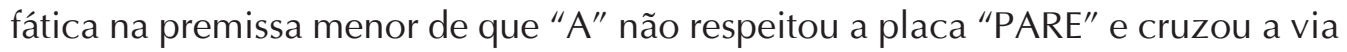
preferencial.

59 Conforme esclarece Greco: "É claro que essa ponderação não precisará ser feita toda vez que o juiz for julgar um acidente de trânsito ou de trabalho, porque, como logo veremos, há normas específicas que regulam estas situações e que devem ser entendidas como concretização do juízo ponderativo" (GRECO, Um panorama da imputação objetiva, p. 58). No mesmo sentido, FRISCH, ob. cit. (nota 52), p. 69; e PUPPE, InDret Penal 1/2021, p. 594. 


\subsubsection{Realização do risco criado no resultado}

Neste ponto encontra-se a segunda matéria arguida pela defesa nas razões de recurso especial, ao afirmar que houve negativa de vigência ao art. 302 do CTB. Para que exista uma conduta típica exige-se, além de um desvalor da ação dado pelo descumprimento da norma de comportamento, de perspectiva ex ante, um desvalor do resultado dado pela ocorrência de um resultado valorativamente negativo pelo ordenamento (norma de valoração), de perspectiva ex post to-61. $^{0}$.

Ocorre que não basta a presença de qualquer resultado negativamente valorado para que esteja presente o chamado desvalor do resultado. Como o Direito Penal tutela bens jurídicos estabelecendo proibições de condutas humanas, o resultado desvalorado sempre será um resultado relativo a uma determinada conduta humana desaprovada ${ }^{62}$, mais especificamente à conduta humana desvalorada ex ante. Exige-se essa relação entre desvalor da conduta e desvalor do resultado, pois a responsabilização de um indivíduo por resultados que não foram a expressão do risco por ele criado, único de que tem controle ${ }^{63}$, não aumentaria a segurança de bens jurídicos, e, por consequência, seria inútil para a função de proteção subsidiária de bens jurídicos.

\subsubsection{Premissa maior}

Essa relação entre a conduta humana desvalorada ex ante e o resultado que se apresentou ex post é estabelecida pelo pressuposto em análise: a realização do risco no resultado, que estará presente quando a proibição da conduta ex ante pelo ordenamento jurídico tiver o objetivo de evitar exatamente o curso

60 GRECO, Funcionalismo e imputação objetiva no direito penal, p. 85.

61 Importante questão, que não pode ser aprofundada neste artigo, diz respeito ao fundamento da exigência do desvalor do resultado como parte da conduta típica, ou seja, por que não basta somente um desvalor da ação, sendo a ocorrência ou não do resultado mera questão de dosimetria de pena ou condição objetiva de punibilidade? Seguiremos aqui a posição de Greco, que afirma que o desvalor do resultado é necessário, pois cumpre a função de confirmação, o que significa dizer que é o desvalor do resultado que demonstra que a proibição da conduta feita ex ante pelo ordenamento jurídico tem justificativa (GRECO, Um panorama da imputação objetiva, p. 101). Do contrário, as normas de proibição do Direito Penal seriam meras proibições de aptidão para atingir bens jurídicos, isto é, proibiria tão somente as desobediências, já justificadas ex ante, não sendo capaz de distinguir sequer os graus de aptidão de cada conduta. Argumentando pela desnecessidade do desvalor do resultado, cf. SANCINETTI, InDret Penal 1/2017.

62 Nesse sentido, GRECO, Um panorama da imputação objetiva, p. 102; FRISCH, ob. cit. (nota 52), p. 87; e SCHÜNEMANN, ob. cit. (nota 40), p. 391-392.

63 GRECO, Funcionalismo e imputação objetiva no direito penal, p. 84-85; e GRECO, Um panorama da imputação objetiva, p. 102. Mencionando uma remota origem da teoria da imputação objetiva a partir da solução ao problema do versari in re illicita enfrentada por juristas do século XVI, cf. ROBLES PLANAS, La imputación objetiva del resultado, p. 21-24. 
causal e o resultado lesivo que ocorreram ex post ${ }^{64}$. Isso é verificado a partir de dois critérios. O primeiro critério é o nexo de aumento do risco ou de evitação do resultado, que analisa se, no caso concreto, a norma de cuidado violada tinha ou não utilidade para evitar o resultado tal qual se observou ex post. Isso porque, caso o resultado se mostre inevitável, ou seja, sua ocorrência se daria mesmo que o autor tivesse agido respeitando a norma de cuidado (comportamento alternativo conforme ao Direito) ${ }^{65-66}$, ele não será a expressão da conduta que ex ante se proibiu, sendo inútil a responsabilização do autor para a proteção de bens jurídicos ${ }^{67}$.

A principal dúvida que surge para esse critério é qual o grau de certeza que se deve exigir para afirmar que o resultado observado teria ocorrido mesmo com um comportamento que cumprisse a norma de cuidado. Ou seja, pergunta-se se é suficiente que, devido às circunstâncias concretas do caso, uma hipotética conduta respeitadora da norma de cuidado diminuiria as chances de ocorrência do resultado (teoria do aumento do risco) ou se é necessário constatar que esta conduta hipotética seria capaz de evitar o resultado com probabilidade próxima

64 GRECO, Um panorama da imputação objetiva, p. 103. Por conta disso, Puppe exige já uma relação de causalidade não só da conduta, mas também da característica que a torna desaprovada juridicamente. Segundo a autora, "é preciso que exatamente aquela característica da ação que constitui a qualidade de ser contrária ao dever é que precisa ser causal para o dano, no sentido de que ela seja parte necessária de uma condição suficiente para sua ocorrência" (PUPPE, Estudos sobre imputação objetiva e subjetiva no direito penal, p. 27; e, também, PUPPE, InDret Penal 1/2021, p. 597-599). Criticando a autora alemã, pois entende que essa relação é puramente normativa e não ontológica, cf. SCHÜNEMANN, ob. cit. (nota 40), p. 397-398.

65 Frisch explica a constelação de casos, que ilustram esse critério, afirmando: "Estes se caracterizam pelo fato de que quem provocou causalmente o resultado o fez atuando de maneira negligente, criando com isso um risco de forma desaprovada. No entanto, nestes casos que agora nos interessam, o resultado teria se produzido igualmente caso 0 atuante tivesse observado as exigências estabelecidas pelo Direito para seu concreto atuar" (FRISCH, ob. cit. (nota 52), p. 88, tradução livre).

66 O caso paradigma que ilustra esse critério é o denominado "caso do ciclista", no qual o motorista de um caminhão realiza a ultrapassagem de um ciclista com uma distância inferior à determinada pelas regras de trânsito e o ciclista acaba caindo sob as rodas do caminhão e morre. Porém, descobriu-se que o ciclista estava bêbado, não sendo possível afirmar que este não cairía mesmo com o caminhoneiro respeitando a distância. A respeito deste caso, cf. GRECO, Um panorama da imputação objetiva, p. 122-125.

67 Nesse sentido, GRECO, Funcionalismo e imputação objetiva no direito penal, p. 87-88. Frisch fundamenta a não imputação do resultado nestas situações afirmando que o resultado que se observou ex post é fruto de um risco residual geral do determinado âmbito social em que se deu a conduta, não sendo necessário indicar a conduta desaprovada do autor ex ante para explicar este resultado, conduta esta que carece então de significado normativo para esse resultado (FRISCH, ob. cit. (nota 52), p. 89). Puppe soluciona essa constelação de casos com a análise da causalidade da característica que torna a conduta desaprovada, chamando-a de problemas de causalidade dupla (PUPPE, ob. cit. (nota 64), p. 33-35). 
da certeza (teoria da evitabilidade) ${ }^{68-69}$. Importante ressaltar que a discussão sobre qual o grau de certeza da não ocorrência do resultado em caso de comportamento alternativo conforme ao Direito que se deve exigir não é uma questão de natureza cognitiva-epistemológica, mas sim de natureza argumentativa-normativa ${ }^{70}$, razão pela qual sua escolha pelo magistrado no caso concreto pode ser impugnada por meio de recurso especial. Essa conclusão fica evidente com a refutação que os autores favoráveis à teoria do aumento do risco fazem do argumento da aplicação do in dubio pro reo ${ }^{71}$.

O segundo critério, e que aqui nos interessa com maior profundidade, é o âmbito do fim de proteção da norma de cuidado. Ao formular sua concepção da teoria da imputação objetiva, Roxin não apresentou clareza a respeito desse critério, simplesmente enunciando uma constelação de casos em que intuitivamente já se entendia que não poderia imputar o resultado ${ }^{72}$. Porém, conforme alerta Greco, não basta afirmar que certo resultado "está ou não no âmbito do fim de proteção da norma", pois esse é mero conceito formal que precisa ser preenchido

68 Sobre essa disputa teórica, cf. GRECO, Um panorama da imputação objetiva, p. 123-124; e GRECO, ob. cit. (nota 42), p. 20-41. A favor da teoria do aumento do risco, Schünemann argumenta: "Deve-se analisar ex post se a norma de cuidado infringida ex ante ainda pode ser considerada, conforme às circunstâncias agora conhecidas, como um meio apropriado político-criminalmente para impedir o resultado produzido. Sem dúvida, as normas que não excluem o risco da produção do resultado em cem por cento, mas somente o reduzem, também são apropriadas desde o ponto de vista político criminal" (SCHÜNEMANN, ob. cit. (nota 40), p. 411-412, tradução livre). A favor da teoria da evitabilidade, argumenta Frisch que, "enquanto o castigo esteja vinculado à existência de um resultado lesivo como resultado injusto, decai a possibilidade de um castigo quando não é possível identificar o resultado observado como injusto. E isto é o que acontece quando não só é teoricamente imaginável, mas também desde uma ótica realista se mostra como possível que o resultado teria se produzido igualmente em caso de dar-se o comportamento conforme ao Direito, isto é, quando resulta possível que o resultado não seja a consequência específica do preciso comportamento contrário ao Direito" (FRISCH, ob. cit. (nota 52), p. 98-99, tradução livre).

69 Puppe soluciona parte desse grupo de casos, na qual autor e vítima infringem deveres de cuidado que lhe são próprios (problemas de dupla causalidade), com a análise da causalidade da característica que torna a conduta desaprovada. Assim, a autora nega a teoria do aumento do risco sob o argumento de que se não há certeza sobre se a lesão do dever de cuidado de um só dos indivíduos é suficiente para a ocorrência do resultado, significa que as duas infrações do dever de cuidado são partes necessárias de uma condição suficiente e, dessa forma, ambos são responsáveis. Com essa argumentação, a autora parece aproximar-se da teoria da evitabilidade, porém, na análise de outro caso, Puppe também nega essa teoria, afirmando que o correto não é perguntar se o autor teria evitado o resultado com o cumprimento do dever, mas sim perguntar se o resultado teria sido evitado se a vítima tivesse cumprido com o seu dever (PUPPE, ob. cit. (nota 64), p. 30-35). No entanto, a autora não fundamenta os motivos pelos quais a pergunta deve ser realizada da perspectiva da vítima, quando o que se está analisando é a conduta desaprovada do autor.

70 Nesse sentido, cf. PUPPE, ob. cit. (nota 9), p. 7-10.

71 Nesse sentido, cf. SCHÜNEMANN, ob. cit. (nota 40), p. 412; e GRECO, ob. cit. (nota 42), p. 32.

72 Para ilustrar, cf. os exemplos mencionados por Roxin, nos quais ele somente afirma que a finalidade do dever de cuidado era diversa da de evitar o resultado que se deu (ROXIN, Estudos de direito penal, p. 111-112). 
por uma cadeia argumentativa para ser aplicado aos $\operatorname{casos}^{73-74}$. Esse critério analisa se o dever de cuidado violado pela conduta ${ }^{75}$ buscava ou não evitar exatamente $o$ resultado ofensivo ao bem jurídico que se observou ex post e por meio do curso causal que efetivamente ocorreu ${ }^{76}$. Isso porque, se o resultado ou o curso causal observados forem diversos daqueles que o dever de cuidado pretendia evitar, já não há uma relação entre a conduta proibida ex ante e o que se observou ex post, não estando cumprinda a função de confirmação ${ }^{77}$ e, por consequência, uma responsabilização pelo resultado em nada melhoraria a segurança do bem jurídico ${ }^{78}$.

Para verificar se o dever de cuidado tem por objetivo evitar o resultado e o curso causal que efetivamente ocorreram ex post, Puppe apresenta consistente formulação. Segundo a autora, o dever de cuidado descumprido teria tal objetivo quando o seu hipotético cumprimento representasse uma evitação - do resultado ou do curso causal observados ex post - que não fosse dependente de casualidades da situação concreta (i. é., uma evitação fortuita), mas sim uma evitação que pode ser apreendida por regras gerais ${ }^{79-80}$. A autora exige, assim, que entre a conduta do autor e o resultado lesivo se estabeleça uma "continuidade de estados

73 GRECO, Um panorama da imputação objetiva, p. 103-104.

74 Interessante notar que, no caso comentado neste artigo, o acórdão a quo do Tribunal de Justiça utiliza exatamente esta forma de argumentação criticada por Greco, ao afirmar: "Ora, patente que se a alta velocidade acarretou risco não permitido, a conduta da ré em adentrar em preferencial elevou o risco de forma relevante com relação à eventual alta velocidade do outro veículo, não podendo dizer que não faz parte do fim de proteção da norma, a circunstância de ingressar em via preferencial, interceptando a trajetória de quem espera que a preferência seja atendida..." (p. 14 do acórdão).

75 Puppe esclarece corretamente que o nexo do fim de proteção da norma diz respeito exclusivamente ao dever de cuidado, e não ao tipo penal. Afirma a autora: "É preciso considerar que a norma cujo âmbito de proteção deva ser esclarecido não consiste no próprio tipo penal. A finalidade da proibição de se matar uma pessoa culposamente é evitar que uma pessoa morra em decorrência da culpa. Não há nada mais o que se dizer a respeito disso. Assim, o objeto de análise da finalidade de proteção apenas pode consistir na relação da lesão do dever de cuidado com a ocorrência do resultado, isto é, a causalidade para o resultado daquelas características do comportamento do agente que são contrárias ao dever de cuidado" (PUPPE, ob. cit. (nota 64), p. 37).

76 GRECO, Um panorama da imputação objetiva, p. 103. Afirmando tratar-se de um critério que deve fazer uma interpretação teleológica da norma de cuidado, cf. SCHÜNEMANN, ob. cit. (nota 40), p. 401.

77 Conforme afirma Greco: "Por não guardarem qualquer relação com o risco criado pelo autor, tais resultados não são por ele evitáveis através da não-prática da ação proibida" (GRECO, Funcionalismo e imputação objetiva no direito penal, p. 87).

78 GRECO, Funcionalismo e imputação objetiva no direito penal, p. 87.

79 PUPPE, ob. cit. (nota 64), p. 37-38. Sobre a posição da autora, cf. GRECO, Funcionalismo e imputação objetiva no direito penal, p. 152-154. Criticando a posição de Puppe, cf. SCHÜNEMANN, ob. cit. (nota 40), p. 400.

80 O caso paradigma para ilustrar esse critério é aquele em que um indivíduo conduz seu veículo acima da velocidade permitida e, posteriormente, quando já está na velocidade adequada, acaba atropelando um pedestre. Nesse caso, poder-se-ia afirmar que se o indivíduo não tivesse desrepeitado a norma de cuidado de velocidade da via anteriormente, não teria atropelado o pedestre. Sobre esse caso, cf. GRECO, Um panorama da imputação objetiva, p. 106. 
de coisas ilícitos", vale dizer, o autor não pode praticar uma conduta que descumpra um dever objetivo de cuidado (normas de segurança) e depois retornar a um estado de criação de risco permitido, quando, então, causa o resultado lesivo, pois, por mais que o resultado somente pudesse ser explicado fazendo menção ao descumprimento do dever de cuidado e o hipótetico cumprimento representasse a evitação deste resultado, tal evitação se daria somente de forma circunstancial, mas não seria uma estratégia idônea para evitá-lo de maneira generalizável ${ }^{81}$.

Portanto, o resultado e o curso causal correspondente não estarão dentro do âmbito do fim de proteção da norma de cuidado quando sua hipotética evitação pelo cumprimento daquela norma se der de maneira fortuita, ou seja, for dependente de casualidades concretas que, se modificadas, não o evitariam.

\subsubsection{Premissa menor}

No caso, conforme acórdão, as provas dos autos demonstraram com probabilidade próxima da certeza que a condutora " $A$ " ultrapassou a preferencial sem respeitar o sinal de "PARE", colidiu com o veículo de "B" e este, por sua vez, com o pedestre "C", que morreu.

\subsubsection{Subsunção}

Caso a condutora "A" tivesse respeitado o sinal de "PARE", as chances de ocorrência da colisão com o veículo " $\mathrm{B}$ " e deste com " $\mathrm{C}$ " seriam menores e, talvez, até evitasse quase que com certeza a ocorrência do resultado letal. Portanto, pode-se afirmar que há um nexo de aumento do risco entre a conduta desvalorada de " $A$ " e o resultado morte de " $C$ ". Ademais, a hipotética evitação do resultado morte de "C" pelo cumprimento do dever de cuidado expresso na placa "PARE" não dependeria de meras casualidades presentes na situação. Ao contrário, a exigência de que se pare o veículo antes de cruzar uma via preferencial procura exatamente evitar colisões de veículos e lesões corporais e mortes dos diferentes participantes do tráfego decorrentes dessas colisões. Em outras palavras, é uma estratégia generalizável para a proteção da vida e da integridade física de pedestres determinar que condutores parem seus veículos antes de atravessar vias preferenciais. Portanto, pode-se afirmar que o resultado morte de "C" observado ex post é a realização do risco juridicamente desaprovado criado por " $\mathrm{A}$ " ex ante ${ }^{82}$.

81 PUPPE, InDret Penal 1/2021, p. 601-603.

82 É possível aqui retomar, de forma breve, a questão relacionada ao fato de "B" estar dirigindo acima da velocidade permitida na via principal, já tratada em parte na nota de rodapé 48 . Caso esse fato tivesse sido provado, a pergunta que se colocaria era se o resultado morte de "C" poderia ser imputado à conduta de "B", excluindo a 


\section{As matérias arguidas pela defesa exigem "reexame de provas"?}

Após a classificação dogmática das matérias arguidas pela defesa no recurso especial, é possível retomar a pergunta guia: O nexo de causalidade (supra, 3.2) e a imputação objetiva do resultado, sobretudo no que se refere à presença do nexo de fim de proteção da norma de cuidado (supra, 3.3.2), exigiriam do Superior Tribunal de Justiça reexame de provas, nos moldes do que proíbe a Súmula $\mathrm{n}^{\mathrm{O}} 7$ ?

Conforme verificado antes, a Súmula $\mathrm{n}^{\circ} 7$ do STJ proíbe a análise e a decisão do Tribunal, a partir de conteúdo já decidido em sentença ou acórdão a quo, sobre se o fato histórico narrado na denúncia ocorreu ou não com probabilidade próxima da certeza.

\subsection{A análise do nexo de causalidade}

O acórdão afirma que a defesa teria alegado ausência de "indícios de nexo de causalidade" entre a conduta de " $\mathrm{A}$ " e a morte de " $\mathrm{C}$ ". Em que pese a frase não se mostre adequada, pois as provas e os indícios procuram reconstruir um fato histórico e não uma lei natural empírica sobre a conexão necessária (ou suficiente) entre eventos, ao que parece a defesa argumentou que não ficou demonstrado com a probabilidade próxima da certeza uma das três alternativas: que houve uma colisão entre o veículo de "A" e o veículo de "B"; uma colisão do veículo de "B" com o pedestre " $C$ " ou lesões de " $C$ " decorrentes da colisão com o veículo de "B".

responsabilidade de "A". Para respondê-la é necessário passar pelas mesmas etapas da imputação objetiva já enfrentadas antes. Ao dirigir acima da velocidade, "B" criou um risco de matar pedestres atropelados. Além disso, é um risco juridicamente desaprovado, pois, de acordo com a norma de segurança da via, prevalece a proteção da vida dos participantes do trânsito em detrimento do exercício da liberdade de dirigir naquela velocidade. Além disso, se ele tivesse cumprido com a norma de segurança de velocidade máxima, com uma probabilidade próxima da certeza, o resultado não teria ocorrido, pois "A" teria condições de desviar ou frear antes da colisão. Ocorre que não é possível imputar o resultado morte de " $\mathrm{C}$ " à suposta conduta desaprovada juridicamente de "B", porque estes não guardam o necessário nexo de proteção da norma, já explicitado no item supra, 3.3.2.1 (sobre o critério, cf. GRECO, Um panorama da imputação objetiva, p. 103). Isso porque a norma de segurança da velocidade máxima busca impedir cursos causais lesivos de choque do veículo em alta velocidade com algo ou alguém, mas, no caso em questão, de acordo com a perícia, o veículo de "A" é que se chocou com a traseira do veículo de "B". Não é uma estratégia generalizável (nesse sentido, cf. PUPPE, ob. cit. (nota 64), p. 37-38) exigir que as pessoas dirigiram em velocidade mais baixa para que não ultrapassem veículos na perpendicular com rapidez e, por consequência, sejam atingidos na traseira. Assim, o cumprimento da norma de cuidado de velocidade por "B" somente evitaria 0 resultado com probabilidade próxima da certeza por casualidade, diferentemente do que ocorre com o hipotético cumprimento da norma de cuidado "PARE" por "A". 
Sendo assim, decidiu corretamente o STJ, pois não cabe ao Tribunal, em sede de recurso especial ${ }^{83}$, verificar a premissa menor, ou seja, se o fato histórico narrado na denúncia foi demonstrado com probabilidade próxima da certeza e, com esta tese, a defesa exigiu mero reexame de provas ao STJ, o que é proibido pela Súmula no 7 .

\subsection{A análise da imputação objetiva, especialmente realização do risco no resultado}

O acórdão afirma que a defesa teria alegado ainda que o dever de cuidado violado pela conduta de " $\mathrm{A}$ " não cobriria a proteção de mortes de pedestres decorrente de colisões de veículos. Esse argumento diz respeito ao denominado âmbito do fim de proteção da norma de cuidado, segundo critério para se definir se o resultado observado foi a realização do risco criado. Mais especificamente, o argumento defensivo trata da etapa da subsunção, negando que o resultado morte de " $\mathrm{C}$ " estivesse no âmbito de proteção da norma de cuidado violada por "A" (placa "PARE").

A análise sobre se o resultado e o curso causal que ocorreram ex post encontram-se ou não dentro do âmbito do fim de proteção da norma de cuidado violada ex ante é um juízo argumentativo/normativo do magistrado, e não cognitivo. Em outras palavras, as partes não precisam provar, mas sim argumentar que o resultado e o curso causal estão ou não no âmbito de proteção da norma e cabe ao magistrado (i) definir qual critério utilizar para responder a essa indagação (premissa maior) e (ii) aplicar seu critério aos fatos provados (subsunção).

Ao argumentar que o resultado morte do pedestre " $\mathrm{C}$ " não estava no âmbito de proteção da norma de cuidado violada por "A", a defesa exigiu corretamente que o STJ se pronunciasse a respeito do processo de subsunção do fato histórico provado ao critério que define o âmbito do fim de proteção da norma de cuidado, indagação essa que tem pretensão de generalização, de verdadeira formação de

83 No que tange ao nexo de causalidade, as partes poderiam arguir em sede de recurso especial qualquer aspecto relacionado com a definição da premissa maior, como, por exemplo, o conceito de causa para o direito penal (causa não seria toda condição necessária para o resultado, mas sim toda componente necessária de uma condição suficiente) ou a definição da lei natural causal (os ferimentos $X$ decorrentes de uma colisão não conduzem à morte) - sobre este aspecto, afirma Badaró: "Também deve ser aceito o recurso contra decisões para controlar a valoração probatória quanto aos princípios gerais da experiência, os conhecimentos científicos, as leis do pensamento e, até mesmo, os fatos notórios" (BADARÓ, ob. cit. (nota 26), p. 285). Seria possível ainda arguir qualquer aspecto relacionado com o processo de subsunção realizado pela sentença ou acórdão a quo, como, por exemplo, a aplicação do conceito de causa e a lei natural escolhidos ao caso concreto (o comportamento da condutora "A" não foi uma condição necessária para o resultado), mas não poderiam arguir que o fato histórico narrado na denúncia não ficou demonstrado com probabilidade próxima da certeza. 
um enunciado jurídico para casos posteriores, o que permite afirmar que se trata da discussão sobre uma negativa de vigência de lei federal (especificamente, a aplicação correta do art. 302 do CTB ao caso) pela decisão a quo.

Sendo assim, o STJ se equivocou nessa parte da decisão, pois deixou de apreciar matéria relacionada à negativa de vigência da lei federal, sob o incorreto argumento de que a tese da defesa exigia reexame de provas, nos termos da Súmula no 7 do STJ. A conclusão correta - se a morte de "C" estava ou não no âmbito de proteção da norma de cuidado ${ }^{84}$ - é aqui de menor importancia, pois o relevante é demonstrar que o STJ podia e devia analisar essa questão por não se tratar de "reexame de provas", mas de intrincada questão dogmática para a qual a doutrina já indicou soluções e critérios diferentes.

\section{Conclusão}

Do que foi exposto pode-se concluir, como resposta à pergunta proposta, que, com relação à primeira das matérias arguidas pela defesa (nexo de causalidade), a solução jurídica do Superior Tribunal de Justiça está correta, pois a impugnação demandaria um reexame sobre se o fato histórico narrado na denúncia estava ou não demonstrado com probabilidade próxima da certeza. Já, com relação à segunda das matérias (âmbito do fim de proteção da norma de cuidado), a solução jurídica do Superior Tribunal de Justiça não está correta, pois trata-se de questionamento sobre a aplicação da premissa maior (requisitos da imputação do resultado ao tipo objetivo) ao fato histórico inquestionável dos autos, ou seja, ao passo da subsunção, de modo que não poderia deixar de analisar a questão sob o argumento da proibição da Súmula no 7 .

Essa conclusão pode servir como alerta em relação a uma indesejável aplicação extensiva e excessiva da Súmula no 7, que tem o potencial de impedir que o STJ deixe de cumprir seu importante mister de uniformização da interpretação das leis (federais) brasileiras ou de, ao menos, estabelecimento das bases conceituais e dogmáticas comuns que devem orientar a aplicação racional do Direito no Brasil.

\section{Referências}

BADARÓ, Gustavo. A inferência probatória e a justificação do juízo de fato no processo penal. In: MALAN, Diogo; BADARÓ, Gustavo; ZILLI, Marcos; ASSIS MOURA, Maria

84 Nossa sugestão de conclusão, com base somente nos elementos do acórdão, foi brevemente manifestada no item supra, 3.3.2. 
Thereza Rocha de; SAAD, Marta; MORAES, Mauricio Zanoide de (Org.). Processo penal humanista. Escritos em homenagem a Antonio Magalhães Gomes Filho. São Paulo: D'Plácido, 2019. p. 71-91.

BADARÓ, Gustavo. Manual dos recursos penais. 2. ed. São Paulo: Revista dos Tribunais, 2017.

COTA, Maria do Carmo; SOUZA, Vinicius Cavalcante de; PARENTE, Francianne Moreira de Carvalho; OLIVEIRA JÚNIOR, José Carlos Coelho de. Recurso especial criminal e Súmula $n^{\circ} 7$ do ST): jurisprudência defensiva $x$ acesso à justiça. Revista de Estudos Criminais, Porto Alegre, n. 66, p. 83-118, 2017.

ENGISCH, Karl. Einführung in das juristische Denken. 11. ed. Stuttgart: Kohlhammer, 2010.

FERRAZ JUNIOR, Tércio Sampaio. Introdução ao estudo do direito. Técnica, decisão, dominação. 4. ed. São Paulo: Atlas, 2003.

FRISCH, Wolfgang. La imputación objetiva del resultado. Desarrollo, fundamentos y cuestiones abiertas sobre la teoría de la imputación del resultado. Trad. Ivó Coca Vila. Barcelona: Atelier, 2015.

FRISCH, Wolfgang. Lo fascinante, lo acertado y lo problemático de la teoría de la imputación objetiva del resultado. In: SANCINETTI, Marcelo A. (Org.). Causalidad, riesgo e imputación. Buenos Aires: Hammurabi, 2009. p. 345-382.

GRECO, Luís. Problemas de causalidade e imputação objetiva nos crimes omissivos impróprios. Trad. Ronan Rocha. São Paulo: Marcial Pons, 2018.

GRECO, Luís. Um panorama da imputação objetiva. 4. ed. São Paulo: Revista dos Tribunais, 2014.

GRECO, Luís. A teoria da imputação objetiva: uma introdução. In: ROXIN, Claus. Funcionalismo e imputação objetiva no direito penal. Rio de Janeiro: Renovar, 2002. p. 1-180.

HASSEMER, Winfried. Sistema jurídico e codificação: a vinculação do juiz à lei. Trad. Marcos Keel. In: KAUFMANN, Arthur; HASSEMER, Winfried (Org.). Introdução à filosofia do direito e à teoria do direito contemporâneas. Lisboa: Fundação Calouste Gulbenkian, 2002. p. 281-301.

HILGENDORF, Eric; VALERIUS, Brian. Direito penal: parte geral. Trad. Orlandino Gleizer. São Paulo: Marcial Pons, 2019.

HUNGRIA, Nélson. Comentários ao Código Penal. 5. ed. Rio de Janeiro: Forense, v. I, t. II, 1978. 
LOPES, José Reinaldo de Lima. Hermenêutica e completude do ordenamento. Revista de Informação legislativa, Brasília, v. 26, n. 104, p. 237-246, 1989. Disponível em: https://www2.senado.leg.br/bdsf/handle/id/181976. Acesso em: 23 dez. 2021.

LOPES JR., Aury. Direito processual penal. 17. ed. São Paulo: Saraiva, 2020.

MARTINELLI, João Paulo; SCHMITT DE BEM, Leonardo. Lições fundamentais de direito penal. Parte geral. 4. ed. São Paulo: Saraiva, 2019.

MUDROVITSCH, Rodrigo de Bittencourt; NÓBREGA, Guilherme Pupe de. Súmula no 7 já faz vezes de repercussão geral no recurso especial. Consultor Jurídico, São Paulo, [n.p.], 31 jul. 2020. Disponível em: https://www.conjur.com.br/2020-jul-31/ improbidade-debate-sumula-faz-vezes-repercussao-geral-recurso-especial. Acesso em: 23 dez. 2021.

PANTALEÓN DÍAZ, Marta. La utilidad de una buena dogmática para una buena jurisprudencia (y viceversa). El ejemplo de la sentencia de la Sala Segunda del Tribunal Supremo 805/2017, de 11 de diciembre (caso "Madrid Arena"). Libertas, [s.I.], n. 7, p. 103-120, 2018.

PUPPE, Ingeborg. A imputação objetiva do resultado a uma ação contrária ao dever de cuidado. Trad. Beatriz Corrêa Camargo. In: PUPPE, Ingeborg. Estudos sobre imputação objetiva e subjetiva no direito penal. São Paulo: Marcial Pons, 2019. p. 19-40.

PUPPE, Ingeborg. Causalidad. Trad. Jesús-María Silva Sánchez. In: PUPPE, Ingeborg; PASTOR MUÑOZ, Nuria (Coord.). El derecho penal como ciencia. Método, teoría del delito, tipicidad y justificación. Buenos Aires: B de F, 2014. p. 209-225.

PUPPE, Ingeborg. Comprobar, imputar, valorar: reflexiones semánticas sobre la fundamentación de sentencias penales y la posibilidad de su revisión jurídica. InDret Penal, Barcelona, n. 3, 2013. Disponível em: https://indret.com/wp-content/themes/ indret/pdf/989.pdf. Acesso em: 23 dez. 2021.

PUPPE, Ingeborg. Definiciones y subsunciones. Trad. Juan Pablo Montiel. Enfoques penales, Buenos Aires, n. 1, [n.p.], 2017. Disponível em: https://www.enletrapenal. com/_files/ugd/e7bffd_882e673bebc1452c9592342818bc029a.pdf. Acesso em: 23 dez. 2021.

PUPPE, Ingeborg. El resultado y su explicación causal en derecho penal. InDret Penal, Barcelona, n. 4, 2008. Disponível em: https://indret.com/wp-content/themes/indret/ pdf/578_es.pdf. Acesso em: 23 dez. 2021.

PUPPE, Ingeborg. El sistema de imputación objetiva. InDret Penal, Barcelona, n. 1, p. 588-613, 2021. Disponível em: https://indret.com/wp-content/uploads/2021/01/1604. pdf. Acesso em: 23 dez. 2021. 
QUARCH, Tilma. Introdução à hermenêutica do direito alemão. Der Gutachtenstil. Revista de Direito Civil Contemporâneo, São Paulo, v. 1, p. 251-285, 2014.

RENGIER, Rudolf. Strafrecht: Allgemeiner Teil. 12. ed. München: C. H. Beck, 2020.

REALE, Miguel. Lições preliminares de direito. 27. ed. São Paulo: Saraiva, 2002.

ROBLES PLANAS, Ricardo. Estudio Preliminar: La "teoría de la imputación objetiva": algunas consideraciones sobre sus orígenes y su futuro. In: FRISCH, Wolfgang. La imputación objetiva del resultado. Desarrollo, fundamentos y cuestiones abiertas. Barcelona: Atelier, 2015. p. 17-40.

ROCHA, Ronan. A relação de causalidade no direito penal. Belo Horizonte: D’Plácido, 2016.

ROSSI, Júlio César. Questão de fato e de direito: por que estamos presos a esse paradigma? Consultor Jurídico, São Paulo, [n.p.], 24 mar. 2018. Disponível em: https://s.conjur.com.br/2018-mar-24/diario-classe-questao-fato-direito-estamos-presosparadigma. Acesso em: 23 dez. 2021.

ROXIN, Claus. A teoria da imputação objetiva. Trad. Luís Greco. In: ROXIN, Claus. Estudos de direito penal. 2. ed. Rio de Janeiro: Renovar, 2008.

ROXIN, Claus. GRECO, Luís. Strafrecht: Allgemeiner Teil. Grundlage. Der Aufbau der Verbrechenslehre. 5. ed. München: C. H. Beck, v. I, 2020.

SANCINETTI, Marcelo Alberto. El disvalor de acción como fundamento de una dogmática jurídico-penal racional. InDret Penal, Barcelona, n. 1, 2017. Disponível em: https://indret.com/wp-content/themes/indret/pdf/1274.pdf. Acesso em: 23 dez. 2021.

SCHÜNEMANN, Bernd. Die Abgrenzung von Tat- und Rechtsfrage in rechtstheoretischer Sicht. In: SCHÜNEMANN, Bernd. Gesammelte Werke: Strafprozessrecht und Strafprozessreform. Berlim: De Gruyter, v. III, 2020. p. 45-80.

SCHÜNEMANN, Bernd. O direito penal é a ultima ratio da proteção de bens jurídicos! Sobre os limites invioláveis do direito penal em um Estado de Direito liberal In: SCHÜNEMANN, Bernd; GRECO, Luís (Coord.). Estudos de direito penal, direito processual penal e filosofia do direito. São Paulo: Marcial Pons, 2013. p. 69-90.

SCHÜNEMANN, Bernd. Espiral ou ovo estrelado? Modelos de aplicação do direito: do modelo hermenêutico ao modelo da filosofia analítica da linguagem. Trad. Danielle Campos. In: SCHÜNEMANN, Bernd; GRECO, Luís (Coord.). Estudos de direito penal, direito processual penal e filosofia do direito. São Paulo: Marcial Pons, 2013.

p. 285-297. 
SCHÜNEMANN, Bernd. Consideraciones sobre la teoría de la imputación objetiva. Trad. Mariana Sacher. In: SCHÜNEMANN, Bernd. Temas actuales y permanentes del derecho penal después del milenio. Madri: Tecnos, 2002. p. 80 ss.

STRECK, Lênio Luiz. Decisão de segundo grau esgota questão de fato? Será que no Butão é assim? Consultor Jurídico, São Paulo, [n.p.], 22 mar. 2018. Disponível em: https:/www.conjur.com.br/2018-mar-22/senso-incomum-segundo-grau-esgota-questaofato-butao-assim. Acesso em: 23 dez. 2021.

\section{Conflito de interesses}

Os autores declaram a ausência de conflito de interesses na produção do presente trabalho.

\section{Sobre os autores:}

Adriano Teixeira | E-mail: ateixeiraguimaraes@gmail.com Doutor em Direito (LMU/Alemanha). Professor (FGV/SP).

Felipe Longobardi Campana | E-mail: fcampana93@gmail.com @gmail.com Graduado (Mackenzie/SP) e mestrando em Direito (USP).

Recebimento: 14.10.2021

Aprovação: 22.12.2021 